\title{
When Britney Spears comes to my lab
}

Now that's what I call pop culture!

\begin{abstract}
Vince LiCata
FOR IMMEDIATE RELEASE: Louisiana native Britney Spears has been considering attending a few classes at the Louisiana State University (LSU) in Baton Rouge, not far from her hometown of Kentwood.
\end{abstract}

When Britney Spears comes to LSU she'll be wearing a silver strapless stretch top that doesn't show too much of her belly (unless she actually moves her arms), and black Capri pants with a little dip in the waistband. Soon after she arrives she'll start working as a student researcher in my laboratory, because, to tell the truth, Intro Biology will be more interesting than she expected. Cutting up dead animals in the student lab will give her an odd, heady rush that she'll find slightly disorientating and mildly pleasant. She'll feel driven to learn more about real scientific research.

I'll teach Britney not to chew gum over the experiments, how to untangle her hair from the $\mathrm{pH}$ meter, and what the label "use only with adequate ventilation" means. Soon she'll get her very own research project, most likely one of our diabetes projects, as the match between a pop star and research on abnormal sugar and lipid metabolism should work well. Britney will pump out a lot of good data (she is something of a workaholic), but gradually, with her music, her intermittent marriages and pregnancies, not to mention her classes, the amount of time she spends in lab will begin to dwindle. I'll give her my standard lecture about commitment, but in the end, Britney will decide to put in more hours at the lab for the same reason all good scientists do: because she likes it.

As Britney becomes more adept and independent in the lab, injuries will become less frequent, as will damage to the equipment. A particularly harrowing incident involving an autotitrator and a Lycra stretch top will induce her to dress more conservatively. Her data will be solid, reproducible and publication-quality. She'll use vacations and breaks to record new songs, and tour during summers. Otherwise, she'll spend a lot of time in the lab, even when it sometimes means flying in and out of town the same day.

After the initial shock, new students will quickly learn that Britney is one of the most productive members of our group. All lab members will learn how to expel annoying reporters, politely and efficiently. The assortment of groupies who will constantly hang around outside our laboratory door will be, for the most part, well-behaved.

Britney's contributions to science will reach far beyond my laboratory. Britney will engender an unprecedented level of public interest in basic science. Funding in all areas of research will reach miraculous new levels.

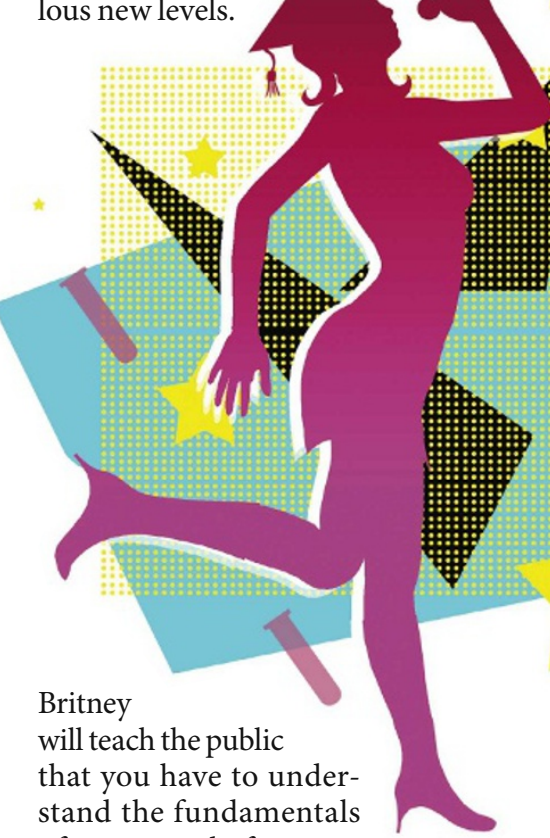
of a system before you can even think about curing a disease. This won't happen overnight. In fact, the first time she's asked about her research on Entertainment Tonight she'll mispronounce the word 'adipocyte'. But soon her public discourse will become error-free and onpoint. The number of young people and other celebrities entering science careers will skyrocket.

After LSU, Britney will go on to earn her $\mathrm{PhD}$ from Harvard. The same month Britney defends her dissertation, she will co-host the Grammys wearing a semitransparent version of a graduation gown and PhD hood. During her postdoctoral work at the Pasteur Institute, she'll adapt well to the French diurnal rhythms: sauntering into the lab around 11, and working till dinner at 10 in her favourite Montparnasse cafe. Her work with whole-animal responses to the antidiabetic treatments she will have developed in graduate school will attract international attention. French journalists, like the Americans before them, will come to accept the fact that they will have to learn some basic biochemistry if they want an interview with Dr Spears.
Britney will spend the next few years setting up her own laboratory and in-lab recording studio at her first faculty position in the Biochemistry Department at St Jude's Children's Hospital in Memphis, Tennessee. Will her colleagues resent her skimpy outfits, that garish eyeliner, and the constantly blaring pop music coming from her lab? Some will, but most will realize that beneath that spandex and body glitter is the heart of a dedicated scientist. Britney's work will uncover promising new avenues for treating diabetes. Unlike many scientists, she'll have to hire security when she gives a research talk. Her yearly FBI report will show that the majority of her stalkers have PhDs.

One night, not many years later, Britney will be sitting alone in a diner on Elvis Presley Boulevard, nursing a cup of coffee, and trying to stay awake in order to go help a student take a late-night time-point. She'll be looking out the window and wondering what her life would have been like if she hadn't spent so much time in the lab and had stayed more involved with her music. The window will reflect the profiles of a woman and a boy sitting in the booth in front of her. The boy will look up from his magazine.

"Mom, what's diabetes?"

"Well, honey, it's a serious disease that has to do with your body not properly digesting sugar. It can make you go blind, or have to have your legs amputated or even kill you."

"Eww. What if I got that?"

"Well, you don't have it, honey, but even if you did, I heard they have a lot of new treatments for it now. I heard Britney Spears works on it."

The boy will go back to his reading. Britney will take another sip of coffee. Looking up, she'll catch the eye of the waitress, and order a slice of pie. She's supposed to be on a diet, but she hasn't shown her belly in public for years, and there's still 20 minutes before she has to be back in the lab.

Vince LiCata is an associate professor of biological sciences at LSU, studying protein structure and function. He also writes plays, which have been produced in several US cities. 